\title{
A new multi-criteria method for the ecological assessment of lakes: A case study from the Transboundary Biosphere Reserve 'West Polesie' (Poland)
}

\author{
Joanna SENDER, ${ }^{1}$ Weronika MAŚLANKO, ${ }^{1}$ Monika RÓŻAŃSKA-BOCZULA,${ }^{2}$ Kevin CIANFAGLIONE ${ }^{3 *}$
}

${ }^{1}$ Department of Landscape Ecology and Nature Conservation, University of Life Sciences in Lublin, 37 B. Dobrzański Street, $20-262$ Lublin, Poland; ${ }^{2}$ Department of Applied Mathematics and Computer Science, University of Life Sciences in Lublin, 28 Głęboka Street, 20-950 Lublin, Poland; ${ }^{3}$ EA 2219 Géoarchitecture, UFR Sciences \& Techniques, Université de Bretagne Occidentale, 6 Avenue Le Gorgeu, CS 93837, 29238 Brest Cedex, France

*Corresponding author: kevin.cianfaglione@univ-brest.fr

\begin{abstract}
A new multi-criteria method of evaluation and assessment of the ecological status of lakes is proposed. It is based on macrophytes analysis integrated with geomorphological, landscape and catchment sources of threats. A total of 22 lakes in the Transboundary Biosphere Reserve 'West Polesie' (Poland) were investigated along trophic (available nutrients) and human pressure gradients, testing the proposed method with ESMI and TRS indices. Therefore, the present indexation included 22 criteria (i.e., catchment land use, phytolittoral area, number of plant species) concerning three different assessing zones (lakeshore, littoral and surrounding area), and provided a five-class ecological classification. The proposed index, in addition to the general ecological conditions assessment of lakes, allows to point out a zonal evaluation, identifying the most critic zones in terms of ecological status. The proposed method can be universally adapted for any type of lakes, regardless of their geographical characteristics. It can be applied to system monitoring, and to support lakes biodiversity, functionality, conservation, restoration, water protection and uses, as well as water, territory and landscape management actions.
\end{abstract}

Key word: Multi-metric Index; macrophytes; lake functionality; ABC method; waters and land management; new proposal.

\section{INTRODUCTION}

The worldwide progressive human pressure on water bodies is among the key causes of aquatic environments decline (Melzer, 1999; Palmer and Roy, 2001; BaattrupPedersen et al., 2006; Brucet et al., 2013). The main causes are burial, erosion, pollution, water characteristics variation (i.e., flow regimes, functionality, physical and chemical changes); together with water bodies, land forms, dynamics artificialization; and biodiversity regression (i.e., Suominen, 1968; Bolpagni et al., 2013; SosseyAlaoui and Rosillon, 2013; Cianfaglione, 2014; Szoszkiewicz et al., 2014; Baláži et al., 2014; Bolpagni and Piotti, 2015, 2016).

To monitor and try to counteract this trend, the development of fast multi-criteria methods, indicating the main causes of the degradation processes, may represent a pivotal choice for introduce effective planning and remedial actions (Villa et al., 2013). Focusing on macrophytes and ecological features, a new multi-criteria method for the ecological status assessment of lakes is presented in order to improve standard methods developed in the frame of the Water Framework Directive (WFD) from European Parliament and Council European Union (2000).

Macrophytes are used successfully in good long time monitoring of ecologic variations, because they are characterized by low mobility (if compared with phytoplank- ton, fishes or invertebrates), and also in a relative short time monitoring because they are closely linked to biodiversity and the environmental conditions (Botineau and Ghestem, 1995; Van der Molen et al., 2004; Kolada, 2008; Cianfaglione, 2011; Khadija et al., 2015; Bolpagni et al., 2016a, 2016b). They are widely used for the aquatic ecosystems assessment, integrating the environmental changes in their frequency, communities structure, phenological rhythm, development (functional traits s.l.), vegetation series and dynamical tendencies (Carvalho et al., 2006; Ali et al., 2007; Feldmann and Nöges, 2007; Sender, 2016; Cianfaglione and Bioret, 2017). For that, macrophytes indices are generally related to the composition, frequency, abundance and presence of specific taxa (Spence, 1967; Suominen, 1968; Newbold and Holmes, 1987; Murphy et al., 1990; Whitton and Kelly, 1995). Despite this, the reliability of the macrophyte-based indices can be limited to (more or less) restricted geographic areas (De Lange and Van Zon, 1983; Holmes et al., 1988; Carbiener et al., 1990; Haury and Peltre, 1993; Stelzer et al., 2005; Haury et al., 2006; Penning et al., 2008).

Until the 90's, the macrophytes were still not so commonly used in the assessment of water quality, but the WFD boosted their role as bioindicators in Europe (i.e., Schneider and Meltzer, 2003; Schaumburg et al., 2004; Meilinger et al., 2005; Stelzer et al., 2005; Kolada, 2008; Pall and Moser, 2009; Sender, 2012a; Bertrin et al., 2012). 
Since 2007, "macrophyte methods" for the diagnosis and monitoring of aquatic ecosystems were recognized as one of the official monitoring methods by the Polish state (Rozporządzenie Ministra Środowiska, 2011), and adopted for monitoring water bodies in Poland (Ciecierska et al., 2010).

\section{METHODS}

\section{Study area}

In 2012, between Poland, Ukraine and Belarus, the 'West Polesie' Transboundary Biosphere Reserve was created. Polish part of the Biosphere Reserve covers the whole mesoregion of the Łęczna-Włodawa Lake District (Wilgat, 1954), also called as Łęczna-Włodawa Plain (Kondracki, 2002). The region is rich in several dozens of lakes, located between the middle course of the Wieprz and Bug rivers; 61 of them are larger than 1 ha, and only 16 lakes are over 50 ha (Chmielewski, 2009). The majority of them are small and shallow lakes, and their formation is associated with the global warming occurred in late Pleistocene and Holocene, after the dissolution/degradation of permafrost and consequent development of thermokarst (Wojtanowicz, 1994).

These lakes are represented by four trophic types (meso-, eu-, hyper-, and dystrophic), undergoing various forms of human pressure. From the end of the 70's of the XX century, most of these lakes were subjected to huge negative changes due to the hydrological regime changes of the area. Also for their originalities, there is no data concerning the current ecological status of these lakes, except only for a small group of them, monitored by the Regional Inspectorate for Environment Protection (Sender, 2012a). Some of them are subjected to very rapid burial processes, eutrophication, banalization of the aquatic communities and species loss. It is estimated that over the last 50 years, from among 68 lakes, five disappeared, and two reduced their surface below 1 ha (Chmielewski, 2009).

The study area corresponds to 22 lakes from the Łęczna-Włodawa Lake District (Fig. 1). These lakes are original in terms of morphology and human pressure diversity, making difficult to assess them by other methods already developed for other Polish lakes; requiring to treat them case by case, individually, as specific sites, showing how it is necessary to implement indexing procedures, to carry out more fine policies and management actions.

\section{Sampling procedures}

Field research was carried out from 2012 to 2014. According to Jensen (1977) and Sender (2009, 2012b), it was conducted through horizontal transects, from the shoreline to the central part of the lakes, following the maximum range of the macrophytes occurrence as possible. Surface of macrophyte communities (coverage), submerged macrophytes share, and species frequency were analysed according to Szmeja (2006). The vegetation was mapped relying on orthophoto-maps (where one pixel representing $0.5 \mathrm{~m}$ in the field) provided by the Polish Head Office of Geodesy and Cartography-Geoportal Web-Site (www.geoportal.gov.pl) ver. 2013, integrating the field observations. This was useful to define vegetation series, interpreting the spatial distribution and surfaces of studied communities according to De Bolòs (1963), Géhu (1991), Biondi (1996), and Rivas-Martinez (1994). This helped us to better define syndynamics (i.e., succession, transgression, regression, fluctuation, regeneration, degeneration) and to relatively adjust the human pressure related values during the assessment (according to Faliński, 1999; Falińska, 2003; Pedrotti, 2013). Surfaces, distributions and phytolittoral were determined by ArcGIS 10.2 software. In order to define plant communities, plant specimens were collected, examined, and identified following Mirek et al. (2002), whereas the syntaxonomic nomenclature follows Matuszkiewicz (2008).

\section{Ecological assessment procedure}

During 70's, macrophytes was rarely used to carry out lake assessments in Poland; Tomaszewicz and Kłosowski (1985) used them in sigma-associations by syn-phytosociological relevés for assessing lakes of the Sejneńskie Lake District.

Macrophyte bio-indicators index (MFI) followed during 80's, also based on the structural-spatial vegetation systems (Rejewski, 1981); not only determining the cover degree, but also the dynamical tendencies by two divergent trends, representing renaturalization $v s$ human impact, indicated as succession (+) and synanthropisation (-). The MFI method was implemented and adapted to the requirements of the WFD, becoming the "Ecological Status Macrophyte Index" (ESMI), accepted to monitor the stagnant lakes in Poland (Ciecierska et al., 2010); however, it is not considerable to be successfully applied to all Polish lake types. In Poland, there are over nine thousands of lakes, and most of them are from glacial origin (Soszka and Cydzik, 2003) as is the case of our study area. ESMI is also considerably not so sensitive to the human pressures that can accelerate the eutrophication, and it should not be applied in lakes where the natural forms can negatively affect the expression of the vegetation (i.e., deepness, slope steepness) limiting the macrophyte communities' expansion (Ciecierska et al., 2006; Ciecierska, 2008; Ciecierska and Kolada, 2014). As example, the ESMI is not successfully applicable to the Polesie region lakes (Ciecierska and Kolada, 2014), because their particular morphology and small water surface: as pointed out by Ciecierska et al. (2006). In most the Polesie region lakes, the phytolittoral is naturally dominated by emergent communities (Sender, 2009); 


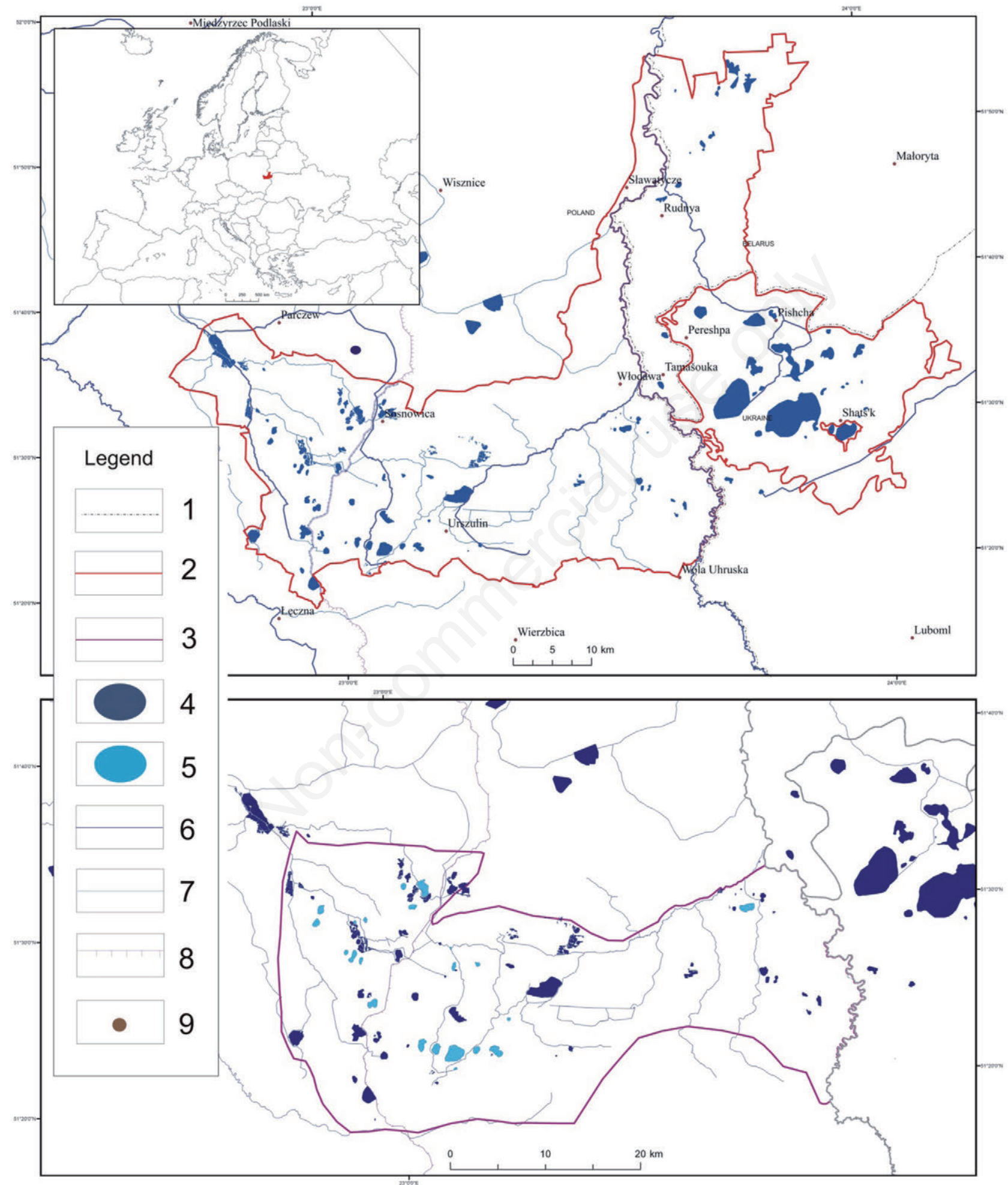

Fig. 1. Investigated area. 1, Polish national border; 2, 'West Polesie’ International Transboundary Biosphere Reserve; 3, Łęczna-Włodawa Lake District; 4, lakes; 5, investigated lakes; 6, main rivers; 7, other rivers; 8, Wieprz-Krzna channel; 9, main settlements. 
the analysis of these lakes, based on others existing indexes showed that the specificity of these lakes requires more elastic methods for their ecological status evaluation, according to Ciecierska et al. (2006).

Following past experiences and these observations, the main goal of our research was to elaborate a new fast and easy to use index, useful to be more generically applied in lakes, assessing their ecological status, paying attention to try to limit the sampling technique and diminish the intersurveyor variability related problems (Kolada et al., 2014). The proposed index is based on macrophyte communities (i.e., non-ligneous plants between Spermatophyta, Pteridophyta, Bryophyta, macroscopic Algae and even some Lichens), integrated with data related to ecology, syndynamics, geomorphology (shoreline, catchment, water chemistry) and land use features (i.e., disturbance, management, threats). Attention was paid to the qualitative and quantitative structure of the macrophytes (Lacoul and Freedman, 2006) as bio-indicator, trying to develop a simple, fast and accurate tool to monitor lake systems. The method we proposed, in addition to the overall assessment of the ecological status of lakes, it provides also an indication of the more threatened zones; making possible to improve their ecological status, reducing threats or fostering restoration activities and landscape planning policies. The catchment analysis was considered necessary because lakes are strongly influenced from its origin, status and structure (Brucet et al., 2013; Bolpagni, 2013; Alahuhta et al., 2014). Therefore, it is assumed that the functioning of the lakes is linked also with lake's features, as well as the lake morphology (Azzella et al., 2014a, 2014b). Following this, the new proposed ABC method offers to determine which factor is the most influential on the lakes functionality, as well to point out which zones are under a negative effect, and which are the main factors that can limit the macrophyte communities' occurrence; trying to understand the more influential factors that can contribute to perturb the vegetation dynamics.

The overall assessment of this proposed method (ABC) was calibrated to the analysis of three predefined zones: catchment (the more external one), shoreline (shallow littoral), and littoral zone (the inner part of water, covered by macrophytes). Three groups of criteria were distinguished: two of them concerned the assessment of lake vegetation quality (A and $\mathrm{B}$ ), whereas the third concerned the assessment of the catchment status (C). For each zone, to understand the human pressure, is necessary to evaluate pollution, modification of land forms and water flows, soil use, and related effect on water/vegetation. To define vegetation changes and dynamics, as possible is also necessary to understand the potential vegetation; and how we are far from it. Roughly is enough, but more it is possible to be precise, more accurate will be the result.
Proposed for small reservoirs evaluation, Juszczak and Arczyńska-Chudy (2003), and Skwierawski (2005) were used as basis model, modifying or replacing few points, concerning the natural variability of biotic and abiotic conditions of lakes, taking as case study the Polesie region.

In the assessment of the shoreline zone (A), we considered the human pressure, and how shoreline communities are far from the potential vegetation. We decided to not consider the peat-bog species presence in the catchment area, because frequently lakes surroundings can be characterized by several other communities with huge ecological difference (i.e., grasslands, fen, cultivations and forests), as it is in the study area. This homogenization better allows comparisons between different types of biotopes. In other hand, in order to eventually underline a remarkable species or a special communities' presence to be monitored, it can be useful to mark them in additional notes. However, we added the number of emergent plant communities because some authors consider them as indicator of changes than individual species (Ciecierska et al., 2006). We paid particular attention also on submerged macrophytes, considered important in ecological assessment of lakes, according to Sondergaard et al. (2010). In evaluation of littoral zone (B) we took in consideration the number of submerged macrophyte communities (pleustonic plants included); share of submerged macrophytes in the lake surface and the total phytolittoral surface. Skwierawski's method focus especially on pleustonic macrophytes, because this group often appears in small reservoirs; but in bigger lakes it occurs more randomly and usually among the helophytes (Wołek and Kościółek, 2012).

As follows, we choose to do not considered few features, when they are not always significant, easy or so fast to know: grouping, replacing, deleting them or adding new points following our goal to develop an efficient, fast, simple and generically applicable evaluation criterion. We did not consider the "water level stability" as single factor, but we considered it between the threats, according to Keto et al. (2006) and Zohary and Ostrovsky (2011) indicating that drastic water level fluctuations (fluctuations out from the normal cyclical ranges) are disadvantageous for aquatic species. Also, waters coming not from the natural water cycle ("alien waters inputs") was considered as threat for similar reasons and for their relative pollution risks. This also allows to relativize and discriminate among the normal natural fluctuations (i.e., per season, per year), to the fluctuation produced by man activities influence: giving more space into the assessment. We replaced also watercolor and turbidity with Secchi disk visibility, giving us an easy and "fast to take" information about light condition and possibilities of submerged macrophytes occurrence. Maximal and minimal values of 
studied feature (Tab. 1) were defined according to Skwierawski (2005). Three intermediate groups were distinguished and progressively numbered, allowing the determination of community conditions.

For the evaluation of shores (A), seven criteria were taken into account: i) shoreline development; ii) share of helophytic communities belonging to Phragmition or Magnocaricion alliances, as emergent macrophytes in shoreline; iii) number of helophytic communities; iv) number of species presence; v) average width of helo- phytes; vi) woodlots and shrubs in the shore zone; and vii) share of helophytes in phytolittoral.

Each feature of evaluation was pointed in a scale from zero to five points (see Tab. 1 about more details). About emergent vegetation, we found more correct to treat this community in sensu stricto; for that, we considered floodable meadows as "out" of shoreline (or marginal), because occurring too far from the shoreline, because of their transitional characteristic (strong amphibious seasonal nature): considering them in catchment analysis, also if

Tab. 1. Assessment criteria of: shoreline zone in lakes (A); lakes littoral zone (B); and lake catchment (C).

\begin{tabular}{|c|c|c|c|c|c|c|c|}
\hline \multirow[t]{3}{*}{ Zone } & \multirow{3}{*}{$\begin{array}{l}\text { Featurel punctuation } \\
\text { Shoreline development }\end{array}$} & \multirow{3}{*}{$\begin{array}{c}5 \\
\text { Heterogeneous }\end{array}$} & 4 & 3 & 2 & 1 & 0 \\
\hline & & & \multicolumn{2}{|c|}{ Diversified slopes } & \multicolumn{2}{|c|}{ Homogeneous slopes } & Converted / \\
\hline & & & $\begin{array}{c}\text { With } \\
\text { abundance of } \\
\text { less steep } \\
\text { slopes }\end{array}$ & $\begin{array}{c}\text { With } \\
\text { abundance } \\
\text { of steep } \\
\text { slopes }\end{array}$ & $\begin{array}{l}\text { Less steep } \\
\text { slopes }\end{array}$ & $\begin{array}{l}\text { Very steep } \\
\text { slopes }\end{array}$ & $\begin{array}{l}\text { anthropic shore } \\
\text { (embanking) }\end{array}$ \\
\hline \multirow[t]{6}{*}{ A } & Share of the belt rushes $(\%)$ in shoreline & $75-100$ & $50-74$ & $25-50$ & $10-25$ & $<10$ & Lack or vestigial \\
\hline & $\begin{array}{l}\text { Number of emergent macrophytes } \\
\text { communities }\end{array}$ & $>10$ & $9-8$ & $7-6$ & $5-4$ & $3-2$ & $>1$ \\
\hline & Number of species & $\begin{array}{l}>20 \text { with rare or } \\
\text { protected species }\end{array}$ & $>20$ & $16-20$ & $15-10$ & $9-6$ & $\begin{array}{l}<5 \text { or with } \\
\text { ruderal species }\end{array}$ \\
\hline & Average width of rushes (m) & $>26$ & $25-21$ & $20-16$ & $15-11$ & $10-6$ & $<5$ \\
\hline & Woodlots and shrubs in the shore zone (\%) & 100 & $99-80$ & $89-60$ & $59-30$ & Single trees & Lack \\
\hline & $\begin{array}{l}\text { Share of emergent macrophytes in } \\
\text { phytolittoral }(\%)\end{array}$ & $<39$ & $40-49$ & $50-59$ & $60-69$ & $70-84$ & $>85$ \\
\hline \multirow[t]{9}{*}{ B } & Secchi disk visibility $(\mathrm{m})$ & $>4.6$ & $4.5-2.5$ & $2.4-1.5$ & $1.4-1.0$ & $0.9-0.5$ & $<0.5$ \\
\hline & Conductivity $\left(\mu \mathrm{s} \cdot \mathrm{cm}^{-1}\right)$ & $<150$ & $151-250$ & $251-350$ & $351-450$ & $451-550$ & $>500$ \\
\hline & Laker surface (ha) & $>300$ & $299-150$ & $149-70$ & $69-30$ & $<29$ & - \\
\hline & Max depth in lake (m) & $>19$ & $19-15$ & $14-10$ & $9-5$ & $4-2$ & $<2$ \\
\hline & $\begin{array}{l}\text { Colonization depth of macrophyte } \\
\text { occurrence (m) }\end{array}$ & $>5$ or to the bottom & $4.5-4$ & $3.9-3$ & $2.9-2$ & $1.9-1$ & $<1$ \\
\hline & $\begin{array}{l}\text { Share of submerged macrophytes } \\
\text { in the lake surface }(\%)\end{array}$ & $>75$ & $74-61$ & $60-46$ & $45-31$ & $30-15$ & $<14$ \\
\hline & Phytolittoral surface $(\%)$ & $50-60$ & $61-70$ & $71-75 ; 49-40$ & $39-30 ; 76-85$ & $29-24 ; 81-80$ & $>90 ;<20$ \\
\hline & $\begin{array}{l}\text { Number of submerged macrophyte } \\
\text { communities }\end{array}$ & $>10$ & $9-8$ & $7-6$ & $5-4$ & $3-2$ & $>1$ \\
\hline & Number of species & 7 with rare or protec & cted 6 & 5 & 4 & 3 & $\leq 2$ \\
\hline \multirow[t]{6}{*}{$\mathrm{C}$} & Catchment area (ha) & $>100$ & $101-200$ & $201-300$ & $301-400$ & $401-500$ & $<500$ \\
\hline & Catchment usage & $\mathrm{F}, \mathrm{P}, \mathrm{G}>75 \%$ & $\mathrm{~F}, \mathrm{P}, \mathrm{G}>50 \%$ & $\begin{array}{l}\mathrm{G}, \mathrm{A}-50-75 \% \\
\quad \mathrm{~B}>25 \%\end{array}$ & $\begin{array}{l}\text { A }>75 \% \\
\text { B } 26-50 \%\end{array}$ & $\mathrm{~B}>50 \%$ & $\begin{array}{c}\mathrm{B}>50 \% \\
\text { lack of sewage }\end{array}$ \\
\hline & Average slope (\%o) & $<2$ & $2-3$ & $3-5$ & $5-10$ & $10-20$ & $>20$ \\
\hline & Type of flow & $\begin{array}{l}\text { Lack of } \\
\text { inflows, } \\
\text { outflows } \\
\text { permanent }\end{array}$ & $\begin{array}{l}\text { Lack of } \\
\text { inflows, } \\
\text { outflows } \\
\text { periodic }\end{array}$ & $\begin{array}{l}\text { Lack of } \\
\text { inflows } \\
\text { and } \\
\text { outflows }\end{array}$ & $\begin{array}{l}\text { Periodic } \\
\text { inflows } \\
\text { and } \\
\text { outflows }\end{array}$ & $\begin{array}{c}\text { Constant } \\
\text { flow } \\
\text { (channel), } \\
\text { periodic } \\
\text { inflow }\end{array}$ & $\begin{array}{l}\text { Only } \\
\text { inflow }\end{array}$ \\
\hline & Threats & $\begin{array}{l}\text { Lack of threats/ } \\
\text { effective form } \\
\text { of protection }\end{array}$ & $\begin{array}{c}\text { Very low } \\
\text { (or occasional/ } \\
\text { potential) } \\
\text { risk }\end{array}$ & $\begin{array}{l}\text { Low } \\
\text { risk }\end{array}$ & $\begin{array}{l}\text { Moderate } \\
\text { risk }\end{array}$ & $\begin{array}{l}\text { High } \\
\text { risk }\end{array}$ & $\begin{array}{l}\text { Very high } \\
\text { risk }\end{array}$ \\
\hline & Ratio of shore length $(\mathrm{m}) /$ capacity $\left(\mathrm{m}^{3}\right)$ & $>0.5$ & $0.6-1.5$ & $1.6-2.5$ & $2.6-3.5$ & $3.6-4.5$ & $<4.6$ \\
\hline
\end{tabular}

F, forest; P, peat-bog; G, grassland; A, agricultural land; B, buildings. 
some helophyte and hygrophyte species can occur. To give adequate values during catchment analysis it is crucial to understand how far we are from the potential vegetation; considering the catchment area status: human influence, plant communities' dynamics (+ or -), and risks. Floodable meadows communities can have an important species diversity and an important productive or cultural importance, but being blocked in an artificial dynamic (anthropogenic fluctuation) they are less in equilibrium, being less quality indicator of trends ( + and -$)$. In that way, more we are distant from the potential vegetation, worst is the catchment value influence. In other hand, when worthy, any secondary plant formations need an additional but apart assessment, specifically calibrated to point out the biodiversity and cultural (heritage) of the landscape: focusing on its functionality, aesthetics, stability, risks, homogeneity/heterogeneity degree, and man uses.

For the assessment of littoral zones (B), nine criteria were taken into account: i) turbidity, as Secchi disk visibility; ii) water conductivity; iii) lake surface; iv) max depth of lake; v) max depth of macrophyte occurrence in lake; vi) share of submerged macrophytes in the lake surface; vii) share of submerged macrophytes in the phytolittoral surface; viii) number of submerged macrophyte communities (with pleustonic and floating leaves plants); and ix) number (amount) of submerged macrophyte species.

The third group of factors (C) consisted of lake surrounding's characteristics and their potential effects on the aquatic ecosystem, including six criteria: i) the catchment area status; ii) the catchment usages; iii) the catchment average slope; iv) type of water flows; v) sources of threats (i.e., industry, agriculture, recreation, anthropogenic transformation of shoreline, pollution); and vi) shore length capacity ratio. In general, all these descriptors allow the assessment of lakes degradation threats, and let us to distinguish five classes of lakes, starting from well-preserved and favorable habitat conditions, to degraded (strongly modified) lakes (Tab. 2), which require corrective/restoration actions (Skwierawski, 2005; Juszczak and ArczyńskaChudy, 2003. Average point values were normalized to indexation in accordance to the guidelines of the WFD scale, from 0.0 to 1.0 . This make possible to distinguish five classes of ecological status of investigated lakes: $\geq 0.90$ (high); 0.89-0.86 (good); 0.85-0.70 (moderate); 0.69-0.64 (poor); and $\leq 0.63$ (bad), according to Ciecierska et al. (2006). At this point, we considered only 14 among 22 lakes, because only they could be successfully compared using others indices. In order to verify the analysis undertaken for selected lakes: the Polish index (ESMI) and the English Trophic Ranking Scores (TRS) were specified (Palmer et al., 1992; Ciecierska, 2008).

An analysis of lake similarity was made regarding three ecological zones A, B, C (in Statistica Software, ver. 10.0). For this purpose, a hierarchical method based on the technique of agglomeration was used. About statistical analysis, concerning the point distance, we adopted the Euclidean distance, whereas the Ward's method was used to estimate the distance between the clusters (Stanisz, 2007).

Tab. 2. Scoring and classification of investigated lakes.

\begin{tabular}{|c|c|c|c|}
\hline Zone & Points & Rank & Interpretation \\
\hline \multirow[t]{5}{*}{$\mathrm{A}+\mathrm{B}$} & $65-55$ & I & Lakes very well preserved, with favorable habitat conditions, with domination of submerged macrophytes \\
\hline & $54-45$ & II & Lakes well preserved with macrophytes in balance \\
\hline & $44-35$ & III & Lakes with slight disturbances, in moderate status, with a slightly dominant group of emergent macrophytes \\
\hline & $34-25$ & IV & $\begin{array}{l}\text { Lakes in poor status, with a significant level of transformation, with a clearly dominant group of emergent macr } \\
\text { phytes; often lack submerged }\end{array}$ \\
\hline & $<24$ & V & Lakes with poor ecological status, degraded or capped by living biomass, often with a lack of macrophytes \\
\hline \multirow[t]{5}{*}{$\mathrm{C}$} & $35-30$ & I & Any danger of degradation \\
\hline & $29-24$ & II & Moderate risk of degradation (1) \\
\hline & $23-18$ & III & Endangered lakes (2-3) \\
\hline & $17-11$ & IV & Significantly endangered lakes (4) \\
\hline & $<10$ & V & Very strong endangered lakes \\
\hline \multirow[t]{5}{*}{$\mathrm{A}+\mathrm{B}+\mathrm{C}$} & $100-85$ & I & Lakes in very good condition: natural valuable \\
\hline & $84-65$ & II & Lakes with high natural values, in good condition, but with some dangers \\
\hline & $64-45$ & III & Lakes with moderate natural values, slightly transformed \\
\hline & $44-25$ & IV & Lakes of slight natural values, very transformed \\
\hline & $<24$ & $\mathrm{~V}$ & Lakes strongly transformed/endangered; requiring restoration or corrective actions \\
\hline
\end{tabular}




\section{RESULTS AND DISCUSSION}

Based on a comprehensive valuation (i.e., considering all the zones in analysis A, B, and C), the majority of the investigated lakes fell in the III quality class (intermediate). This category included lakes with moderate natural values and risk of degradation (corresponding to the $59.1 \%$ of the 22 lakes alias 13 lakes). The lowest values were found in two lakes (Uścimowskie and Zienkowskie) that exhibited a poor ecological status (IV class); despite they showed significantly differences in terms of water surface and quality. However, they both had the catchment area devoted mainly to agricultural purposes, and they both served as wastewater receivers. In other hand, by our assessment, we not found lakes in the worst class (V class, namely degraded), frequently characterized by scarce and banal plants presence; often without aquatic plants; requiring attentions or urgent interventions (Fig. 2).

Getting a look to the quality assessment of the surrounding areas $(\mathrm{C})$, we observed a clear predominance of lakes in IV class (5). There were also lakes included in the $\mathrm{V}$ class, corresponding mainly to lakes embedded in a strongly human impacted landscape. Based on the analysis of the littoral zone (B), the largest lake group was the one with moderate natural values and slightly perturbed (III class) (Fig. 3).

Comparing the ecological assessment at zonal (A, B and C) scale, especially for lakes felling into III class, we identified the zones characterized by the highest rates of perturbation. In general, the shoreline zone (A) reached the highest value in all lakes except those that fell in II class, whereas littoral zone (B) was highly evaluated in III and
IV class categories of lakes. In the lakes where the catchment was dominated by agricultural land and buildings, the catchment zone (C) reached the lowest values (Fig. 3). Białe Włodawskie, Bialskie, Piaseczno, Rotcze, Uściwierz, and Moszne lakes were evaluated as lakes with a high natural value and a slight risk of degradation, namely with a high ecological value (II class), although of their significant seasonal anthropogenic pressure (i.e., touristic/recreational purposes) (Fig. 3). Due to their rather high depth and large surface, these ecosystems seemed to be enough resistant to this touristic type of pressure.

Lakes in the II class are characterized by the presence of several Chara species, and by the dominance of submerged macrophytic beds. An exception was represented by the Lake Moszne, that is shallow, polymictic, and subject to a full preservation by the highest level of Polish law protection.

The analysis of the lake similarity based on the analyzed parameters allowed us to identify three clusters with very similar conditions. The first cluster contained the most impacted and degraded lakes (Zienkowskie, Uścimowskie, Gumienko, Sumin, Gumienek, Białe Sosnowickie) (S1). The second group included lakes in III class, typically eutrophic lakes subjected to various forms of pressure, with well-developed submerged macrophyte beds (Płotycze Urszulińskie, Głębokie Uścimowskie, Ściegienne, Miejskie, Bikcze, Firlej, Krasne, Rotcze, Moszne, and Czarne Sosnowickie lakes) (S2). The third group contained the best-preserved lakes (II class), with the presence of several Chara species (Maśluchowskie, Uściwierz, Kleszczów, Piaseczno, Białe Włodawskie, Bialskie lakes) (S3) (Fig. 4).

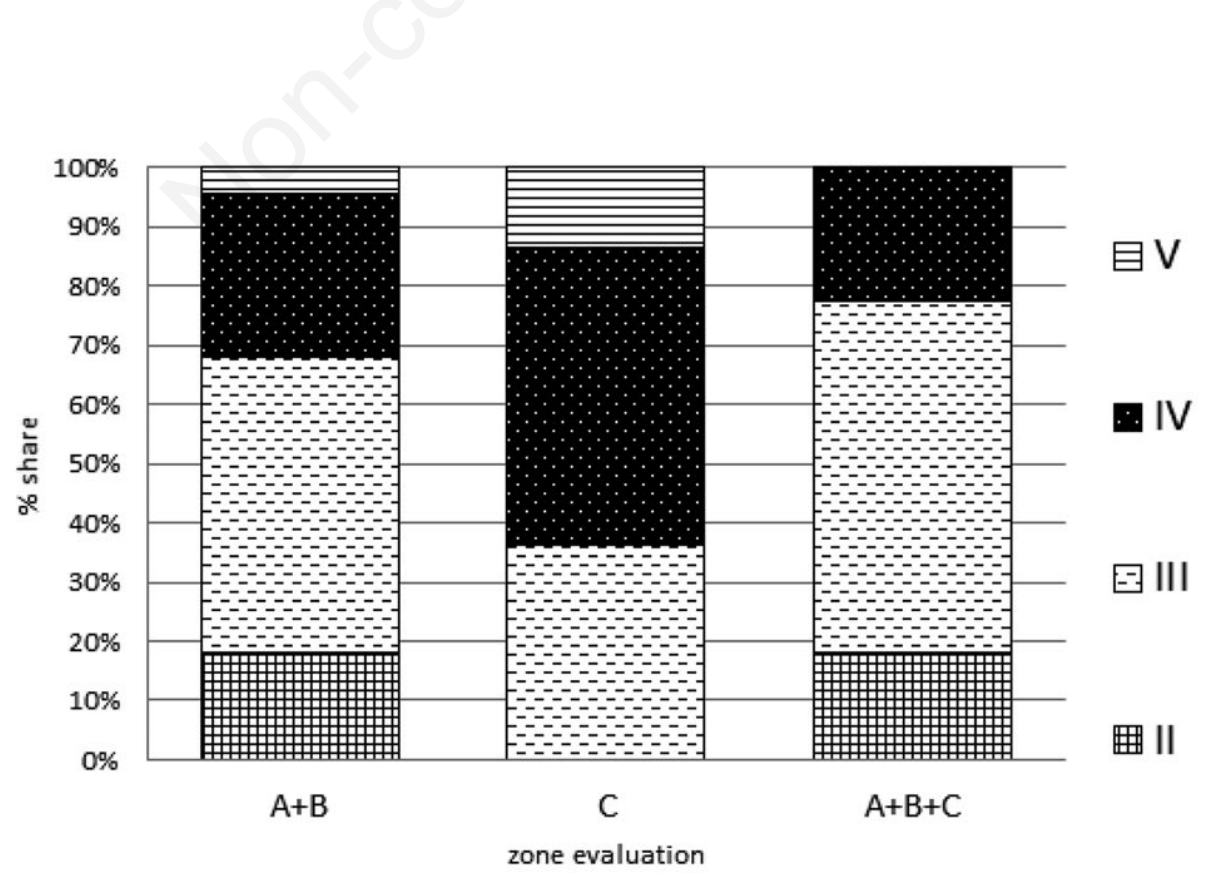

Fig. 2. Percentage share of lakes with different classes of evaluation (II-IV class of lakes). 


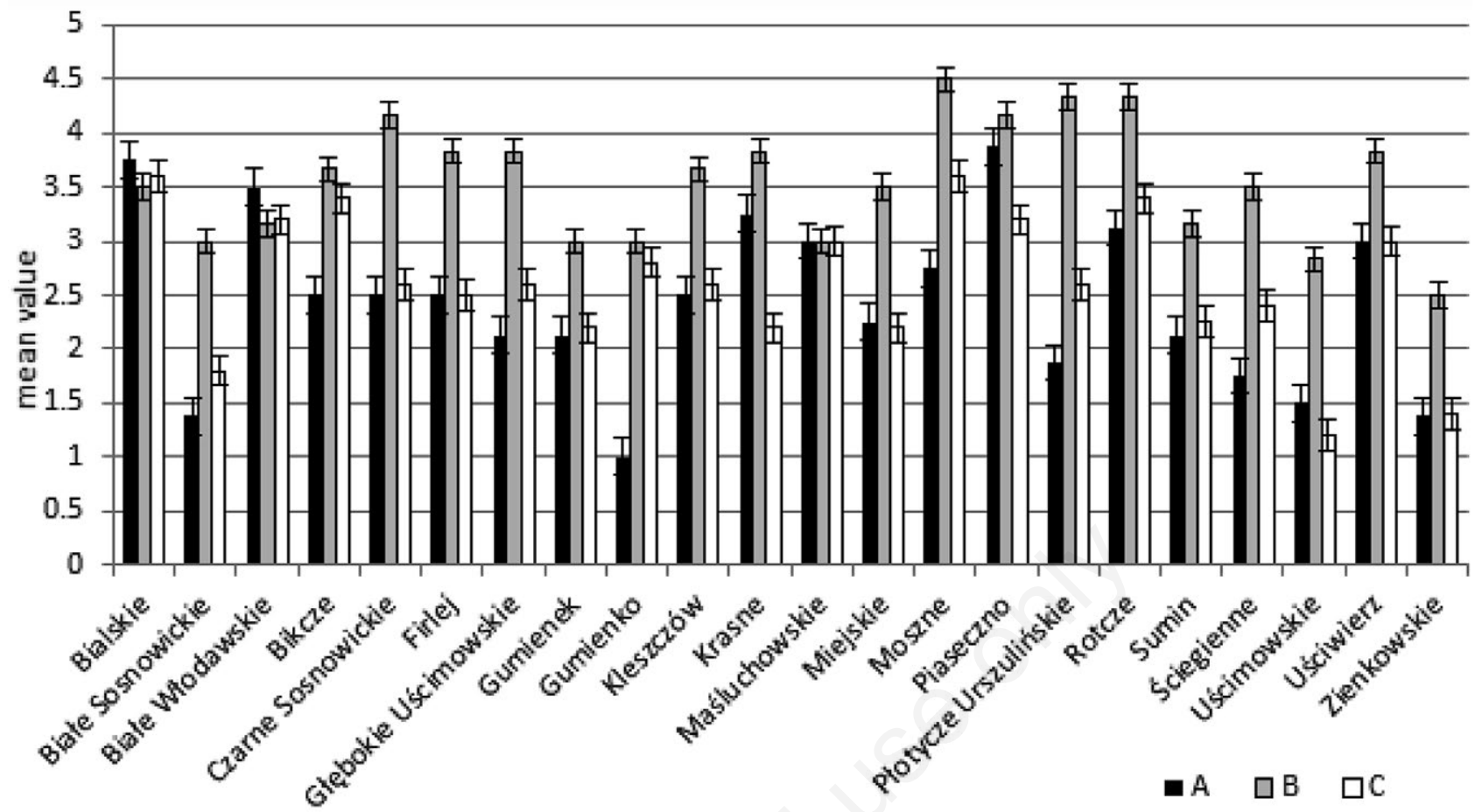

Fig. 3. Average value of evaluation for each zone (A, of shore; B, littoral; C, catchment).

UPGMA

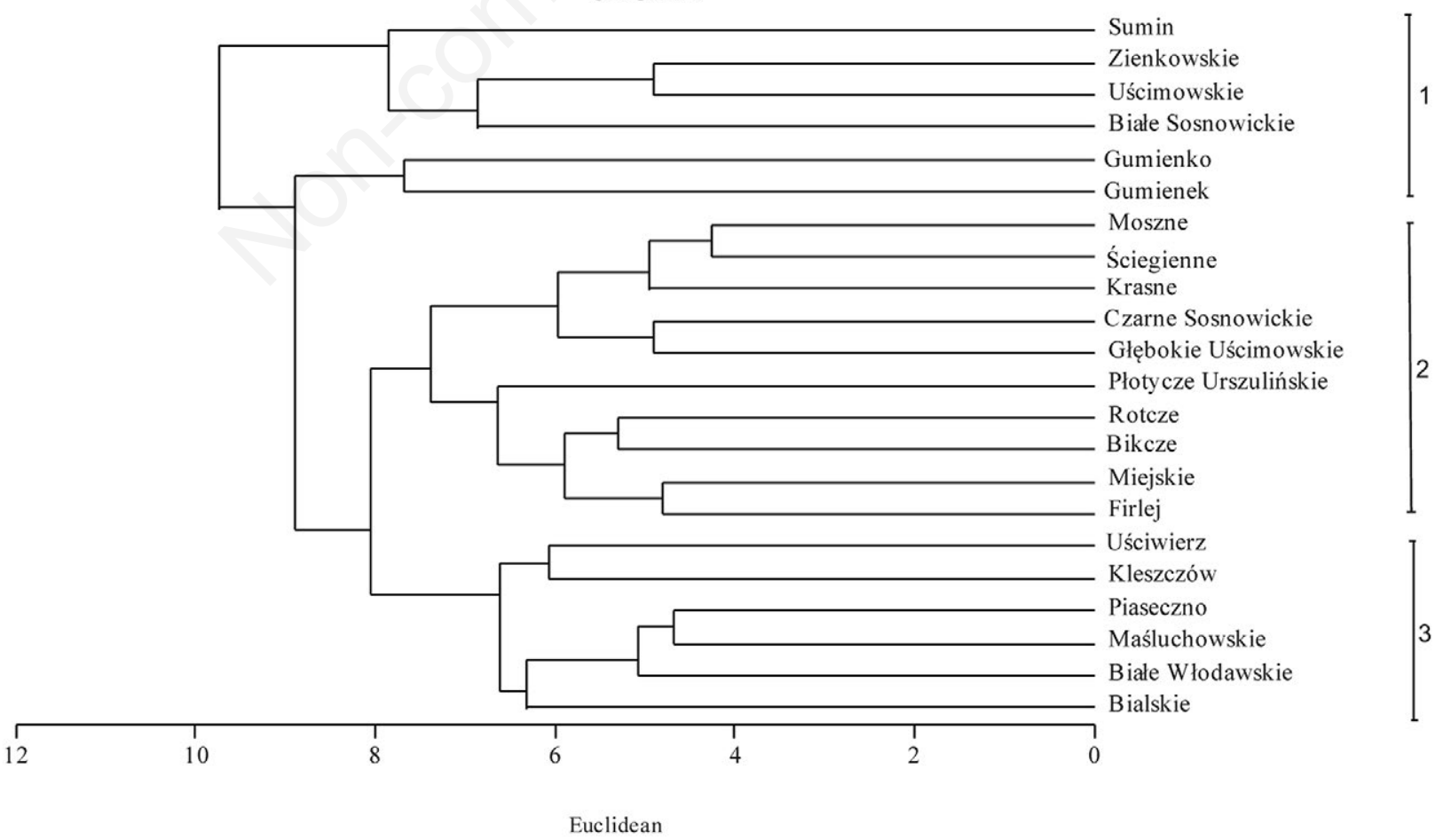

Fig. 4. Mean of similarity coefficient of examined lakes: $1(=\mathrm{S} 1), 2(=\mathrm{S} 2), 3(=\mathrm{S} 3)$ groups of lakes. 
A test of variance analysis (Tab. 3) clearly indicated that all the investigated zones are extremely important and significant in the overall valuation and assessment of the ecological status of the lakes, determining the membership into a specific group (category) $(\mathrm{P}<0.05)$. The statistical analysis of any zone (A, B, and C) of lakes (Fig. 4) showed that lakes belonging to the degraded lakes group (S1) had the lowest values in all analyzed zones; constituting a group of lakes that has strongly differing parameters from the average status. After analyzing lakes falling in the others two groups, it can be concluded that lakes in the second group (S2, eutrophic) were much better from the viewpoint of the littoral and surrounding zones (B and C), while worse from the shore conditions (A). This trend substantially changed for the lakes in the third group (S3), with the highest overall assessments and the best ecological status, for each zone.

The three identified lake classes showed a clear difference in vegetation types, in terms of macrophyte communities' distribution. Some of floating leaves plant communities (i.e., Nupharo-Nymphaeetum albae Tomasz. 1977, Potametum natantis Soó 1923, Hydrocharitetum morsus-ranae Langendonck 1935, Nymphaeetum candidae Miljan 1958), and pleustophytes [i.e., Lemno minorisSalvinietum natantis (Slavnić 1956) Korneck 1959, Lemnetum trisulcae (Kelhofer 1915) Knapp et Stoffers 1962, Spirodeletum polyrhizae (Kelhofer 1915) Koch 1954 em. R.Tx. et A. Schwabe 1974 in R.Tx.1974] occurred in lakes with the lowest ecological value. The clear domination of helophytic communities [among them Scirpetum lacustris (Allorge 1922) Chouard 1924, Typhetum angustifoliae (Allorge 1922) Soó 1927, Phragmitetum australis (Gams 1927) Schmale 1939, Typhetum latifoliae Soó 1927, Thelypteridi-Phragmitetum Kuiper 1957, Caricetum acutiformis Sauer 1937, Phalaridetum arundinaceae (Koch 1926 n.n.) Lib. 1931, Caricetum ripariae Soó 1928 and others similar but less represented communities] occurred in lakes with good and moderate ecological status. The most balanced participation of all macrophyte groups occurred in lakes with the highest value of evaluation (II class) (Fig. 5). Kendall's correlation between ecological status and the number of the different groups of macrophytes in each lake was medium but significant $(\tau=0.52, \mathrm{P}<0.05)$.

\section{ABC method evaluation versus other macrophyte indexes}

We used and compared the ABC method with two different, widely used, macrophyte-based indexes elaborated for assessing the ecological status of lakes: The Polish "ESMI", and the English "TRS". The ecological status assessment obtained using the ESMI index and the present method (ABC) showed a slight similarity (38\%), whereas the lowest similarity was between $\mathrm{ABC}$ index and TRS index (only 15\%). The Pearson's correlation coefficient (comparing $\mathrm{ABC}$ and $\mathrm{ESMI}$ ) was $\mathrm{r}=0.62, \mathrm{P}<0.05$. Lakes fell into I and II classes were mesotrophic or slightly eutrophic, in any case they can be considered in a good functional status. The greater differences were found among lakes felling into III class, namely eutrophic lakes. Comparing ESMI and ABC method, few lakes showed different results. Values were lower for seven lakes, five were the same and two higher (Tab. 4). These differences probably are due to the ESMI method, that is based on littoral zone data, and submerged macrophytes are its main element of evaluation. In our system, we also propose more factors to take under control, than ESMI is more focused to underline the human pressure as eutrophication process, however, lakes are subject also to others pressures.

Smallest differences in lake's ecological values were observed between the ABC and the English TRS index, but following this method, the largest group belongs from eutrophic lakes. In our opinion, this view can be too generic, because between eutrophic lakes it is possible to find different stages of eutrophication, combined not always with human pressure. In this way, our method try to combine a wide range of parameters (between vegetation, ecological features and uses) that can influence macrophytes community. The ABC method could be applied to all types of lakes, regardless the lake size/shape, the macrophyte occurrence, trophy or lake origin. Analyzing the different zones ( $\mathrm{A}, \mathrm{B}$ and $\mathrm{C}$ ) it is possible to know which one is in poor condition, differing to others methods based only on macrophytes and less focused on ecological and dynamical features assessment.

The results allow to define lakes ecological status and which zones of them may require remedial action. For this reason, the $\mathrm{ABC}$ index can be applied to support biodi-

Tab. 3. Variance analysis test of A, B and C zones.

\begin{tabular}{llllllr}
\hline Svar & SSb & df & SSw & di & F & Pvalue \\
\hline A & 15.89 & 2 & 5.11 & 19 & 29.53 & $<0.001$ \\
\hline B & 15.78 & 2 & 5.22 & 19 & 28.69 & 0.000002 \\
\hline C & 13.68 & 2 & 7.32 & 19 & 17.76 & 0.000045
\end{tabular}

Svar, Source of variation; SS, sum of square; SSb, SS between; $d f$, degrees of freedom; SSw, SS within; F, F test; A, lakes; B, lakes littoral zone; C, lake catchment. 
versity, functionality, uses, conservation, restoration, water, territory and landscape management actions.

\section{Practical remarks on the use of phytosociological approach in lakes analysis}

In our proposal, it is possible to use any known type of plant/community "nomenclature approach", and any method to assess the vegetation cover. We opted for the phytosociological approach to discriminate the recorded vegetation under a standardized and hierarchized framework. In this way, it was possible to place any communities in a syntaxon by a known procedure. Using this type of communities' decoupage/nomenclature lets us to be more fine discriminating between similar communities; being universal, because if necessary, the holotypes are published and relevés can be converted into others

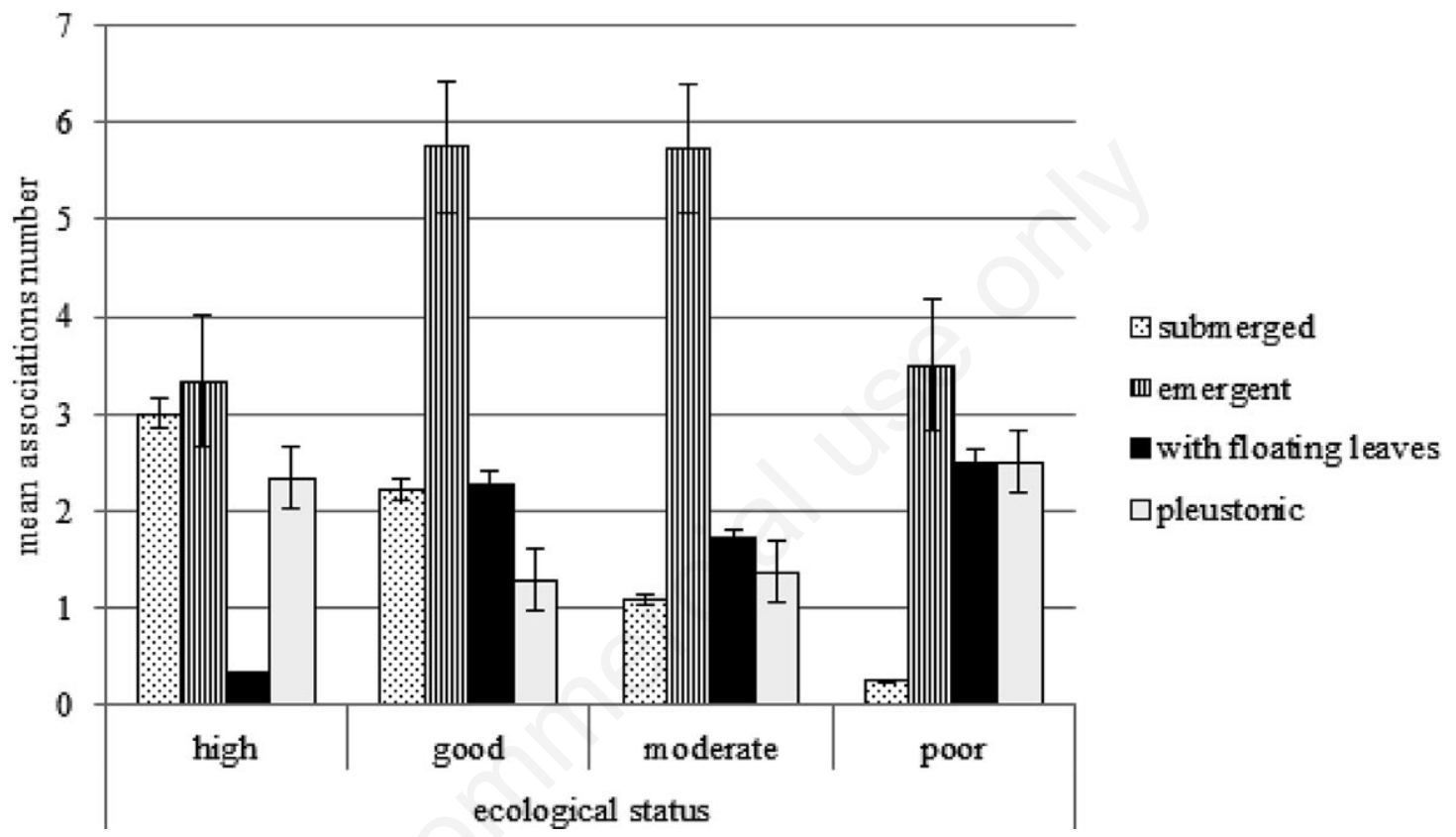

Fig. 5. Macrophyte groups/plant associations' ratio, per different ecological lake status type.

Tab. 4. Ecological status assessment of selected lakes by different compared methods.

\begin{tabular}{lcccccc} 
& EBC & Status & ESMI & Status & TRS & Status \\
Lake & 0.91 & Very good & 0.74 & Very good & 7.1 & Mesotrophic \\
\hline Białe Włodawskie & 0.83 & Moderate & 0.514 & Good & 8.2 & Eutrophic \\
\hline Firlej & 0.83 & Moderate & 0.34 & Good & 8.1 & Eutrophic \\
\hline Głębokie Uścimowskie & 0.82 & Moderate & 0.99 & Very good & 7.3 & Mesotrophic \\
\hline Kleszczów & 0.87 & Good & 0.5 & Good & 8.0 & Eutrophic \\
\hline Krasne & 0.86 & Good & 0.95 & Very good & 8.0 & Eutrophic \\
\hline Maśluchowskie & 0.77 & Moderate & 0.67 & Good & 8.2 & Eutrophic \\
\hline Miejskie & 0.90 & Very good & 0.88 & Very good & 8.1 & Eutrophic \\
\hline Moszne & 0.95 & Very good & 0.8 & Very good & 8.0 & Eutrophic \\
\hline Piaseczno & 0.81 & Moderate & 0.455 & Good & 8.3 & Eutrophic \\
\hline Płotycze Urszulińskie & 0.90 & Very good & 0.394 & Good & 7.9 & Mesotrophic \\
\hline Rotcze & 0.76 & Moderate & 0.104 & Poor & 8.4 & Eutrophic \\
\hline Sumin & 0.90 & Very good & 0.83 & Very good & 8.2 & Eutrophic \\
\hline Uściwierz & 0.68 & Poor & 0.207 & Moderate & 8.6 & Hypertrophic
\end{tabular}


nomenclatural approaches. In addition, when necessary (i.e., communities with new floristic combination, or not well expressed) it is possible to know the relevés accuracy level by the hierarchic syntaxon used (i.e., group, variant, association, sub-association, alliance, etc.). According to some authors, similar communities, or communities dominated by the same species, are not necessary similar in ecological, floristic or geobotanical traits, reflecting a different ecological value (Whittaker, 1962; Westhoff and Van der Maarel, 1973; Whittaker, 1975; Pott, 1995; Willner et al., 2009; Lötter et al., 2013; Pérez-Harguindeguy et al., 2013; Pillar et al., 2013). Consequently, these communities can differ in type of response to global changes (i.e., climate, land uses, water, pollution, artificialization, burial), needing different management strategies.

In the context of the debated conceptual problems about biological communities' definition and their limits, we believe that the integration of ecology with nomenclature and empirical approaches based on plant sociology may be an interesting fast way to study, classifying, and cataloguing plant communities. These approaches need to be more explored as useful tool in the solution of biogeography and ecology problems (Poore, 1955; Jennings et al., 2003; Blasi and Frondoni, 2011; Van der Maarel, 2012; Cianfaglione and Pedrotti, 2016), and relative applications as proposed in certain ways from others authors (i.e., Faliński, 1993; Gillet and Gallandat, 1996; Mucina, 1997; Pedrotti, 1999; Biondi, 2011; Decocq, 2016).

\section{Ecological remarks}

Bearing in mind that the use of the macrophyte index ESMI for most lakes of Polesie is not possible, an attempt was made to develop alternative method for assessing a macrophytes based on ecological status of lakes. In this way, our index allows to determine the lakes ecological status, and in other hand it can be helpful applied to choose methods and scope of protection/restoration policies, allowing to determine which zone require more remedial action. Our observations underlined that even the highest environmental protection standards cannot guarantee from the "risks" if a human pressure is (potentially) present. Certainly, they help to limit (and prevent) the risk, but they cannot ensure the preservation of habitats or the natural dynamics constancy, according to Kopeć et al. (2011). For example, until the late 90's Lake Moszne was frequently inhabited by stonewort mats [i.e., Charetum aculeolatae (Corillion 1957) Dąmbska 1966, and Charetum fragilis Corillion 1949], recently replaced by a dense and more banal watermilfoil stands (Myriophylletum spicati Soó 1927), according to Sender (2008). As known, there are many factors influencing resilience and resistance to the lakes degradation. Observations in study area confirmed this, and personal observations (made by the authors mainly in Poland, but also in France and in Italy) underlined how the resilience of lakes appear greater, when the surface and depth are greater, according to Azzella et al. (2014a) and Sender et al. (2014). Smaller and shallower lakes are easier to fill and pollute, with a relative overgrowth of Phragmitetalia australis communities and other graminoids communities, so-called "roseliere" (sensu Géhu, 2006) formations.

In evaluation of water ecosystem ecological status, the catchment plays a highly important role (Sender et al., 2014; Szoszkiewicz et al., 2014), also as buffer zone (Alahuhta et al., 2014). Both, the presence of intensive/extensive agriculture and housing in catchment areas, as well as the lack of a buffer zone in surveyed lakes, usually decreased their quality: adversely affecting plants occurrence (i.e., Uścimowskie, and Zienowskie lakes). Definitely, the highest value lakes were in the deepest lakes, with a large share of bogs, grasslands and forests in their catchments: that resulted in the dominance of submerged macrophytes in phytolittoral, and a significant share of Charophyta (Piaseczno, Bialskie, and Białe Włodawskie lakes).

A dominance of emergent macrophytes, the disappearance of submerged vegetation in lakes or a depletion of the species composition may suggest that the deteriorating light conditions (turbidity) is related to burial, or mass development of phytoplankton (Sondergaard et al., 2010). The spread of "roseliere" means a progressive process of burial, with graminoids communities' overgrowth, transforming it into a sort of sedge, fen or "flat peat-bog"; and burial rates can increase to very high levels following human pressure. Urbanization, deforestation or logging, modification of landforms or water flow, industrial or agricultural development, pollution and eutrophication can easily amplify that process (Arbuckle and Downing, 2001; Heathcote and Downing, 2012; Sender, 2012c; Sawtschuk and Bioret, 2012). Land use can also amplify the burial process because lakes receive increased erosional loads (Bennett et al., 2001), and the volume of sediment deposited per unit time varies in a function of lake and watershed size: smaller impoundments had greater deposition and accumulation rates per unit area (Downing et al., 2008). Also in forested areas, the patterns of increasing sediment and nutrient delivery are remarkable, directly after deforestation, logging or land clearance (Rask et al., 1998; Dearing and Jones, 2003; Sender, 2016). Less is known about temporal trends related to other land cover types (such as grasslands), which may substantially differ in response to land clearance, according to Jobbágy and Jackson (2000) hypothesis, also if more in general consequences can be presumably similar.

\section{CONCLUSIONS}

The studied lakes in the Lęczna-Włodawa Lake District shows a different ecological status, concerning con- 
servation and functionality. Macrophytes and functional conditions of the surroundings were a basis for their classification. The $\mathrm{ABC}$ method for lakes ecological status assessment, allowed us to distinguish them into five classes. The largest group was the one with a good or moderate ecological status. The zones with the lowest values, often demanding remedial actions, were pointed out. In the overall assessment of the lakes ecological status, all the zones (A, B and C) demonstrated to be extremely important, affecting the functionality of the aquatic ecosystems.

The results of this newly index as a system of lakes status evaluation was comparable to the Ecological Status Macrophyte Index (ESMI), especially for lakes with a high natural value; however, its application is wider, and allows a more accurate representation of the actual ecological status, risks and functionality, by zones.

\section{REFERENCES}

Alahuhta J, Kanninen A, Hellsten S, Vuori K, Kuoppala M, Hämäläinen H, 2014. Variable response of functional macrophyte groups to lake characteristics, land use, and space: implications for bioassessment. Hydrobiologia 737:201-214.

Ali MM, Mageedb AA, Heikal M, 2007. Importance of aquatic macrophyte for invertebrate diversity in large subtropical reservoir. Limnologica 37:155-169.

Arbuckle KE, Downing JA, 2001. The influence of watershed land use on lake N:P in a predominantly agricultural landscape. Limnol. Oceanogr. 46:970-975.

Azzella MM, Bolpagni R, Oggioni A, 2014a. A preliminary evaluation of lake morphometric traits influence on the maximum colonization depth of aquatic plants. J. Limnol. 73:400-406.

Azzella MM, Rosati L, Iberite M, Bolpagni R, Blasi C, 2014b. Changes in aquatic plants in the Italian volcanic-lake system detected using current data and historical records. Aquat. Bot. 112:41-47.

Baattrup-Pedersen A, Szoszkiewicz K, Nijboer R, O'Hare M, Ferreira T, 2006. Macrophyte communities in unimpacted European streams: variability in assemblage patterns, abundance and diversity. Hydrobiologia 566:179-196.

Baláži P, Hrivnák R, Ot’ahelová H, 2014. The relationship between macrophyte assemblages and selected environmental variables in reservoirs of Slovakia examined for the purpose of ecological assessment. Pol. J. Ecol. 62:541-558.

Bennett EM, Carpenter SR, Caraco NF, 2001. Human impact on erodable phosphorus and eutrophication: A global perspective. BioScience 51:227-234.

Bertrin V, Boutry S, Dutartre A, 2012. Ecological quality assessment of lakes based on aquatic macrophyte assemblages in the context of the Water Framework Directive (WFD): The French Macrophyte Index for lakes (IBML). Journees Internationales de Limnologie et d'Oceanographie, ClermontFerrand, France: 18 pp.

Biondi E, 1996. [L'analisi fitosociologica nello studio integrato del paesaggio, p. 13-22].[In Italian]. In: J. Loidi (ed.), Proceedings $1^{\text {st }}$ Symp. on "Avances en Fitosociología”, Universidad del Pais Vasco.
Biondi E, 2011. Phytosociology today: methodological and conceptual evolution. Plant Bios. 145:19-29.

Blasi C, Frondoni R, 2011. Modern perspectives for plant sociology: the case of ecological land classification and the ecoregions of Italy. Plant Biol. 145:30-37.

Bolpagni R, 2013. Multimetric indices based on vegetation data for assessing ecological and hydromorphological quality of a man-regulated lake. Ann. Bot. (Roma) 3:87-95.

Bolpagni R, Piotti A, 2015. Hydro-hygrophilous vegetation diversity and distribution patterns in riverine wetlands in an agricultural landscape: a case study from the Oglio River (Po plain, Northern Italy). Phytocenologia 45:69-83.

Bolpagni R, Piotti A, 2016. The importance of being natural in a human-altered riverscape: Role of wetland type in supporting habitat heterogeneity and vegetation functional diversity. Aquat. Conserv. 26:1168-1183.

Bolpagni R, Laini A, Azzella MM, 2016a. Short-term dynamics of submerged aquatic vegetation diversity and abundance in deep lakes. Appl. Veg. Sci. 19:711-723.

Bolpagni R, Racchetti E, Laini A, 2016b. Fragmentation and groundwater supply as major drivers of algal and plant diversity and relative cover dynamics along a highly modified lowland river. Sci. Tot. Environ. 568:875-884.

Bolpagni R, Bettoni E, Bonomi F, Bresciani M, Caraffini K, Costaraoss S, Giacomazzi F, Monauni C, Montanari P, Mosconi MC, Oggioni A, Pellegrini G, Zampieri C, 2013. Charophytes of Garda Lake (Northern Italy): A preliminary assessment of diversity and distribution. J. Limnol. 72: 388-393.

Botineau M, Ghestem A, 1995. Caractérisation des communautés de macrophytes aquatiques (plantes vasculaires, bryophytes, lichen) en Limousin. Leurs relations avec la qualité de l'eau. Acta Bot. Gall. 142:585-594.

Brucet S, Poikane S, Lyche-Solheim A, Birk S, 2013. Biological assessment of European lakes: ecological rationale and human impacts. Freshwater Biol. 58:1106-1115.

Carbiener R, Trémolières M, Mercier JL, Orcheit A, 1990. Aquatic macrophyte communities as bioindicators of eutrophication in calcareous oligosaprobe stream waters (Upper Rhine plain, Alsace). Vegetatio 86:71-88.

Carvalho L, Lepisto L, Rissanen J, Pietilainen O P, Rekolainen S, Torok L, Lyche Solheim A, Saloranta T, Ptacnik R, Tartari G, Cardoso AC, Premazzi G, Gunn I, Penning E, Hanganu J, Hellsten S, Orhan I, Navodaru I, 2006. Nutrients and eutrophication in lakes, p. 3-32. In: A. Solimini, A.C. Cardoso and A.S. Heiskanen (eds.), Indicators and methods for the ecological status assessment under the Water Framework Directive: Linkages between chemical and biological quality of surface waters. Official Publications of the European Communities, Luxembourg.

Chmielewski TJ, 2009. [Ekologia krajobrazów hydrogenicznych Rezerwatu Biosfery Polesie Zachodnie].[Book in Polish]. Wydawnictwo Uniwersytet Przyrodniczy w Lublinie: 344 pp.

Cianfaglione K, 2011. The Ricciocarpetum natantis association in the Springs of Capo Pescara, Abruzzo (Italy). In A. Bensetiti, F. Bioret, and F. Pedrotti (eds.), Centenarie de la Phytosociologie. Braun-Blanquetia 46:186-190.

Cianfaglione K, 2014. The variations of water level and influence of artificial regulations in marshy woodland of Alnus glutinosa in the Peligna Valley (Abruzzo, central Italy): 4 
years of investigation. Contribuții Botanice 49:121-127.

Cianfaglione K, Pedrotti F, 2016. The vegetation of the Pie' Vettore Debris (Sibillini Mountains, Central Italy), p. 363-374. In: E.O. Box (ed.), Vegetation structure and function at multiple spatial, temporal and conceptual scales. Springer, Dordrecht.

Cianfaglione K, Bioret F (2017). Autoecological and synecological resilience of Angelica heterocarpa M.J. Lloyd, observed in the Loire Estuary (France). In: A. Greller, K. Fujiwara and F. Pedrotti (eds.), Geographical changes in vegetation and plant functional types. Geobotany studies. Springer, Dordrecht (In press).

Ciecierska H, 2008. [Makrofity jako wskaźniki stanu ekologicznego jezior. Rozprawy i Monografie].[Book in Polish]. Wydawnictwo Uniwersytetu Warmińsko-Mazurskiego w Olsztynie: 139 pp.

Ciecierska H, Kolada A, 2014. ESMI a macrophyte index for assessing the ecological status of lakes. Environ. Monit. Assess. 186:5501-5517.

Ciecierska H, Kolada A, Soszka H, Gołub M, 2006. [Opracowanie podstaw metodycznych dla monitoringu biologicznego wód powierzchniowych w zakresie makrofitów i pilotowe ich zastosowanie dla części wód reprezentujących wybrane kategorie i typy. Etap II Opracowanie metodyki badań terenowych makrofitów na potrzeby rutynowego monitoringu wód oraz metoda oceny i klasyfikacji stanu ekologicznego wód na podstawie makrofitów, Tom 2, Jeziora].[Book in Polish]. Narodowego Funduszu Ochrony Środowiska i Gospodarki Wodnej. IOŚ-UWM, WarszawaOlsztyn.

Ciecierska H, Kolada A, Soszka H, Gołub M, 2010. A method for macrophyte-based assessment of the ecological status of lakes, developed and implemented for the purpose of environmental protection in Poland. BALWOIS, Ohrid.

De Bolòs O, 1963. [Botánica y Geografía].[Article in Spanish]. Memorias Real Academia Ciencias y Artes Barcelona 34:443-480.

De Lange L, Van Zon JCJ, 1983. A system for the evaluation of aquatic biotypes based on the composition of macrophyte vegetation. Biol. Conserv. 25:273-284.

Dearing JA, Jones RT, 2003. Coupling temporal and spatial dimensions of global sediment flux through lake and marine sediment records. Global. Planet. Change 39:147-168.

Decocq G, 2016. Moving from patterns to processes: A challenge for the phytosociology of the twenty-first century?, p. 407-424. In: E.O. Box (ed.), Vegetation structure and function at multiple spatial, temporal and conceptual scales. Springer, Dordrecht.

Downing JA, Cole JJ, Middelburg JJ, Striegl RG, Duarte CM, Kortelainen P, Prairie YT, Laube KA, 2008. Sediment organic carbon burial in agriculturally eutrophic impoundments over the last century. Global. Biogeochem. Cy. 22:GB1018.

European Union, 2000. Directive 2000/60/EC of the European Parliament and of the Council of 23 October 2000 establishing a framework for Community action in the field of water policy. OJ L 327, 22/12/2000, p. 1-73.

Faliński JB, 1993. Applied geobotany and "ecologization" of geobotanical map. Fragm. Florist. Geobot. 2:501-512.

Faliński JB, 1999. Geobotanical cartography: subject, source basis, transformation and application fundamentals of maps. Phytocoenosis Suppl. Cart. Geobot. 11:43-65.

Falińska K, 2003. Alternative pathways of succession: species turnover patterns in meadows abandoned for 30 years. Phytocoenosis Archiv. Geobot. 9:1-104.

Feldmann T, Nöges P, 2007. Factors controlling macrophyte distribution in large shallow Lake Vortsjarv. Aquat. Bot. 87:15-21.

Géhu JM, 1991. [L'analyse phytosociologique et géosymphytosociologique de l'espace. Théorie et méthodologie].[Article in French]. Colloq. Phytosoc 17:11-46.

Géhu JM, 2006. [Dictionnaire de sociologie et synécologie végétales].[Book in French]. J. Cramer Ed., Berlin-Stuttgart, Germany: 899 pp.

Gillet F, Gallandat, JD, 1996. Integrated synusial phytosociology: some notes on a new, multiscalar approach to vegetation analysis. J. Veg. Sci. 7:13-18.

Haury J, Peltre MC, 1993. [Intérêts et limites des «indices macrophytes» pour qualifier la mésologie et la physicochimie des cours d'eau: exemples armoricains, picards et lorrains].[Article in French]. Ann. Limnol. 29:239-253.

Haury J, Peltre MC, Trémoliéres M, Barbe J, Thiébaut G, Bernez I, Daniel H, Chatenet P, Haan-Archipof G, Muller S, Dutartre A, Laplace-Treyture C, Cazaubon A, Lambert-Servien E, 2006. A new method to assess water trophy and organic pollution - the Macrophyte Biological Index for Rivers (IBMR): its application to different types of river and pollution. Hydrobiologia 570:153-158.

Heathcote AJ, Downing JA, 2012. Impacts of eutrophication on carbon burial in freshwater lakes in an intensively agricultural landscape. Ecosystems 15:60-70.

Holmes NTH, Boon P J, Rowell TA, 1988. Revised classification for British rivers based on their plant communities. Aquat. Conserv. 8:555-578.

Jennings M, Loucks O, Glenn-Lewin D, Peet R, Faber-Langendoen D, Grossman D, Damman A, Barbour M, Pfister R, Walker M, Talbot S, Walker J, Hartshorn G, Waggoner G, Abrams M, Hill A, Roberts D, Tart D, 2003. Guidelines for describing Associations and Alliances of the U.S. National vegetation classification. The Ecological Society of America. Vegetation Classification Panel, vers. 2.0; March 28.

Jensen S, 1977. An objective method for sampling the macrophytes vegetation in lakes. Vegetatio 33:107-118.

Jobbágy EG, Jackson RB, 2000. The vertical distribution of soil organic carbon and its relation to climate and vegetation. Ecol. Appl. 10:423-436.

Juszczak R, Arczyńska-Chudy E, 2003. [Ekologiczna i melioracyjna waloryzacja małych zbiorników wodnych w krajobrazie rolniczym Wielkopolski].[Article in Polish]. Zeszyty Problemowe Postępów Nauk Rolniczych 1:145-160.

Keto A, Tarvainen A, Hellsten S, 2006. The effect of water level regulation on species richness and abundance of aquatic macrophytes in Finnish lakes. Verh. Int. Verein Limnol. 29:2103-2108.

Khadija SA, Francis R, Bernard T, 2015. Trend analysis in ecological status and macrophytic characterization of watercourses: Case of the Semois-Chiers Basin, Belgium Wallonia. J. Water Res. Prot. 7:988-1000.

Kolada A, 2008. [Wykorzystanie makrofitów w ocenie jakości jezior w Europie w świetle wymogów Ramowej Dyrektywy 
Wodnej - przegląd zagadnienia].[Article in Polish]. Ochrona Środowiska i Zasobów Naturalnych 37:24-42.

Kolada A, Ciecierska H, Ruszczyńska J, Dynowski P, 2014. Sampling techniques and inter-surveyor variability as sources of uncertainty in Polish macrophyte based metric for lake ecological status assessment. Hydrobiologia 737:256-279.

Kondracki J, 2002. [Geografia regionalna Polski].[Book in Polish]. Wydawnictwo PWN, Warszawa: 440 pp.

Kopeć D, Halladin-Dąbrowska A, Zając I, 2011. Flora dynamics in strictly protected nature reserve. Pol. J. Environ. Stud. 20:107-113.

Lacoul P, Freedman B, 2006. Environmental influences on aquatic plants in freshwater ecosystems. Environ. Rev. 14:89-136.

Lötter MC, Mucina L, Witkowski ETF, 2013. The classification conundrum: species fidelity as leading criterion in search of a rigorous method to classify a complex forest data set. Comm. Ecol. 14:121-132.

Matuszkiewicz W, 2008. [Przewodnik do oznaczania zbiorowisk roślinnych Polski].[Book in Polish]. Wyd. Naukowe PWN, Warszawa: 536 pp.

Meilinger P, Schneider S, Melzer A, 2005. The reference index method for the Macrophyte based assessment of rivers - A contribution to the implementation of the European Water Framework Directive in Germany. Int. Rev. Hydrob. 90:322-342.

Melzer A, 1999. Aquatic macrophyres as tools for lake management. Hydrobiologia 395/396:181-190.

Mirek Z, Piękoś-Mirkowa H, Zając A, Zając M, 2002. Flowering plants and pteridophytes of Poland, a checklist. Szafer Inst. of Botany, Polish Academy of Sciences, Kraków: 442 pp.

Mucina L, 1997. Classification of vegetation: Past, present, and future. J. Veg. Sci. 8:751-760.

Murphy KJ, Rorslett B, Springuel I, 1990. Strategy analysis of submerged lake macrophytes communities: an international example. Aquat. Bot. 36:303-323.

Newbold C, Holmes NTH, 1987. Nature conservation: water quality criteria and plants as water quality monitors. Water Pollut. Control. 86:345-364.

Pall K, Moser V, 2009. Austrian Index Macrophytes (AIM-Module 1) for lakes: A Water Framework Directive compliant assessment system for lakes using aquatic macrophytes. Hydrobiologia 633:83-104.

Palmer MA, Bell SL, Butterfield I, 1992. A botanical classification of standing waters in Britain: applications for conservation and monitoring. Aquat. Conserv. 2:125-143.

Palmer MA, Roy DB, 2001. A method for estimating the extent of standing fresh waters of different trophic states in Great Britain. Aquat. Conserv. 11:199-216.

Pedrotti F, 1999. [Cartografia della vegetazione e qualità dell'ambiente].[Article in Italian]. Nat. Alp. 4:21-41.

Pedrotti F, 2013. Plant and vegetation mapping. Springer, Dordrecht: 249 pp.

Penning E, Mjelde M, Dudley B, Hellsten S, Hanganu J, Kolada A, Van Den Berg M, Mäemets H, Poikane S, Phillips G, Willby N, Ecke F, 2008. Classifying aquatic macrophytes as indicators of eutrophication in European Lakes. Aquat. Ecol. 42:237-251.

Pérez-Harguindeguy N, Díaz S, Garnier E, Lavorel S, Poorter H, Jaureguiberry P, Bret-Harte M, Cornwell WK, Craine JM,
Gurvich DE, Urcelay C, Veneklaas EJ, Reich PB, Poorter L, Wright IJ, Ray P, Enrico L, Pausas JG, de Vos AC, Buchmann N, Funes G, Quétier F, Hodgson JG, Thompson K, Morgan HD, ter Steege H, van der Heijden MGA, Sack L, Blonder B, Poschlod p, Vaieretti MV, Conti G, Staver AC, Aquino S, Cornelissen JHC, 2013. New handbook for standardised measurement of plant functional traits worldwide. Aust. J. Bot. 61:167-234.

Pillar VD, Blanco CC, Müller SC, Sosinski EE, Joner F, Duarte LDS, 2013. Functional redundancy and stability in plant communities. J. Veg. Sci. 24:963-974.

Poore MED, 1955. The use of phytosociological methods in ecological investigations. J. Ecol. 43:226-244.

Pott R, 1995. [Die Pflanzengesellschaften Deutschlands].[Book in German]. Ulmer, Stuttgart.

Rask M, Nyberg K, Markkanen SL, Ojala A, 1998. Forestry in catchments: Effects on water quality, plankton, zoobenthos and fish in small lakes. Boreal Environ. Res. 3:75-86.

Rejewski M, 1981. [Roślinność jezior rejonu Laski w Borach Tucholskich].[Book in Polish]. Uniwersytet Mikołaja Kopernika, Rozprawy, Torun.

Rivas-Martinez S, 1994. Dynamic-zonal phytosociology as landscape science. Phytocoenologia 24:23-25.

Rozporządzenie Ministra Środowiska, 2011. [R. w sprawie klasyfikacji stanu ekologicznego, potencjału ekologicznego i stanu chemicznego jednolitych części wód powierzchniowych].[Report in Polish]. Dz.U. 2011, nr 258, poz. 1549.

Sawtschuk J, Bioret F, 2012. [Analyse diachronique de la dynamique spatiale de la végétation de l'estuaire de la Loire. Photo-Interprétation].[Article in French]. Eur. J. Appl. Remote Sensing 3:15-28.

Schaumburg J, Schranz C, Hofmann G, Stelzer, Schneider S, 2004. Macrophytes and phytobenthos as indicators of ecological status in German lakes - a contribution of the implementation of the Water Framework Directive. Limnologica 34:302-314.

Schneider S, Meltzer A, 2003. The trophic index of macrophytes (TIM) - A new tool for indicating the trophic state of running waters. Int. Rev. Hydrobiol. 88:49-67.

Sender J, 2008. Long term changes of macrophytes in the Lake Moszne (Poleski National Park). Teka Komisji Ochrony i Kształtowania Środowiska Przyrodniczego Oddział Lublin PAN 5:154-163.

Sender J, 2009. [Analiza zmian sukcesyjnych zachodzących w fitocenozach wodnych i florze makrolitów badanych jezior w latach 1960-2009, p. 139-161]. In: T.J. Chmielewski (ed.), [Ekologia krajobrazów hydrogenicznych Rezerwatu Biosfery Polesie Zachodnie].[Book in Polish]. Wyd. UP Lublin.

Sender J, 2012a. Possibilities of macrophyte indicators, application for assessment of ecological status of lakes. Transylv. Rev. System. Ecol. Res. 14:115-128.

Sender J, 2012b. Quantitative investigations of vascular flora in deep and shallow eutrophic lake. Teka Komisji Ochrony i Kształtowania Środowiska Przyrodniczego Oddział Lublin PAN 9:215-223.

Sender J, 2012c. The dynamics of macrophytes in a lake in an agricultural landscape. Limnol. Rev. 2:93-100.

Sender J, 2016. The effect of riparian forest shade on the structural characteristics of macrophytes in a mid-forest lake. Appl. Ecol. Environ. Res. 14:249-261. 
Sender J, Cianfaglione K, Kolejko M, 2014. Evaluation of ecological state of small water reservoirs in the Bystrzyca river valley. Teka Komisji Ochrony i Kształtowania Środowiska Przyrodniczego Oddział Lublin PAN 11:173-180.

Skwierawski A, 2005. [Ocena stanu małych zbiorników wodnych na terenach wiejskich. Cz. I. Metoda waloryzacji małych zbiorników].[Article in Polish]. Zeszyty Problemowe Postępów Nauk Rolniczych 506:391-402.

Sondergaard M, Johansson L, Lauridsen TL, Jorgensen TB, Liboriussen L, Jeppesen E, 2010. Submerged macrophytes as indicator of ecological quality of lakes. Freshwater Biol. 55:893-908.

Sossey-Alaoui K, Rosillon F, 2013. Macrophytic distribution and trophic state of some natural and impacted watercourses-Belgium Wallonia. Int. J. Water Sci. 2:1-11.

Soszka H, Cydzik D, 2003. Changes in water quality of Polish lakes in the years 1991-2000 (based on lake monitoring results). Limnol. Rev. 3:53-58.

Spence DHN, 1967. Factor controlling the distribution of freshwater macrophytes with particular reference to the lochs of Scotland. J. Ecol. 55:147-170.

Stanisz A, 2007. [Przystępny kurs statystyki z zastosowaniem].[Book in Polish].Statistica PL na przykładach z medycyny, Kraków vol.3.

Stelzer D, Schneider S, Melzer A, 2005. Macrophyte-based assessment of lakes - a contribution to the implementation of European Water Framework Directive in Germany. Int. Rev. Hydrobiol. 90:223-237.

Suominen J, 1968. Changes in the aquatic macro-flora of the polluted lake Rautrvesi. SD.W. Finland. Ann. Bot. Fenn. 5:65-81.

Szmeja J, 2006. [Przewodnik do badań roślinności wodnej].[Book in Polish]. Wyd. UG, Gdańsk: 307 pp.

Szoszkiewicz K, Ciecierska H, Kolada A, Schneider SC, Szwabińska M, Ruszczyńska J, 2014. Parameters structuring macrophyte communities in rivers and lakes - results from a case study in North-Central Poland. Knowl. Manag. Aquat. Ecosyst. 415:08.
Tomaszewicz H, Kłosowski S, 1985. [Roślinność wodna i szuwarowa jezior na Pojezierzu Sejneńskim].[Article in Polish]. Monogr. Bot. 67:69-141.

Van der Maarel E, 2012. Vegetation ecology - an overview, p. 1-51. In: E. Van der Maarel and J. Franklin (eds.), Vegetation ecology, 2nd ed. Wiley-Blackwell.

Van der Molen DT, Latour P, Stronkhorst J, Van der Wal B, 2004. [Ecologische referenties en maatlatten voor de Kaderrichtlijn Water].[Article in Dutch]. H2O 6:10-12.

Villa P, Laini A, Bresciani M, Bolpagni R. 2013. A remote sensing approach to monitor the conservation status of lacustrine Phragmites australis beds. Wetl. Ecol. Manag. 21:399-416.

Westhoff V, van der Maarel E, 1973. The Braun-Blanquet approach, p. 617-726. In: R.H. Whittaker (ed.), Handbook of vegetation science. Part 5, Classification and ordination of communities. Junk, The Hague.

Whittaker H, 1962. Classification of natural communities. Bot. Rev. 28:1-239.

Whittaker RH, 1975. Communities and ecosystems. MacMillan Publishing, London: 352 pp.

Whitton BA, Kelly MG, 1995. Use of algae and other plants for monitoring rivers. Aust. J. Ecol. 20:45-56.

Wilgat T, 1954. [Jeziora Łęczyńsko-Włodawskie].[Article in Polish]. Annales UMCS, sec. B 8:37-122.

Willner W, Tichy L, Chytry M, 2009. Effects of different fidelity measures and contexts on the determination of diagnostic species. J. Veg. Sci. 20:130-137.

Wojtanowicz J, 1994. [O termokrasowej genezie Jezior Łęczyńsko-Włodawskich].[Article in Polish]. Annales UMCS sec. B 49:1-18.

Wołek J, Kościółek A, 2012. [Występowanie, struktura i ekologia zbiorowisk pleustonowych (klasa Lemnetea minoris) w województwie małopolskim (Polska)].[Article in Polish]. Fragm. Florist. Geobot. Polon. 19:99-115.

Zohary T, Ostrovsky I, 2011. Ecological impacts of excessive water level fluctuations in stratified freshwater lakes Tamar. Inland Waters 1:47-59. 